\title{
Validation of a Romanian Scale to Detect Antenatal Depression
}

\author{
Anne B. Wallis ${ }^{1,2 *}$, Roberto Fernandez ${ }^{3}$, Florin Oprescu², \\ Răzvan Cherecheş ${ }^{2,4}$, Alina Zlati ${ }^{2}$, Claibourne I. Dungy ${ }^{1,5,6}$ \\ 'Department of Epidemiology, College of Public Health, University of lowa, \\ 200 Hawkins Drive, lowa City, Iowa, 52242, USA \\ ${ }^{2}$ Open Minds: Center for Mental Health Research, \\ Mehedinți 35, 400675, Cluj-Napoca, Romania \\ ${ }^{3}$ College of Osteopathic Medicine, Des Moines University, \\ 3200 Grand Avenue, Des Moines, Iowa, 50312, USA \\ ${ }^{4}$ Department of Occupational and Environmental Health, College of Public Health, University of lowa, \\ 124 IREH, UI Research Park, lowa City, lowa, 52242, USA \\ ${ }^{5}$ Department of Pediatrics, Children's Hospital of lowa, University of lowa, \\ 2633 Carver Pavillion, 200 Hawkins Drive, Iowa City, Iowa, 52242, USA \\ ${ }^{6}$ College of Law, University of lowa, \\ 130 Byington Road, lowa City, lowa, 52242, USA
}

\section{Received 13 January 2011; Accepted 14 November 2011}

Abstract: The aim of this study was to develop and validate a linguistically and culturally appropriate version of the Edinburgh Postnatal Depression Scale (EPDS) for use with women attending antenatal care in Romania. We translated and tested a Romanian version of the EPDS (EPDS-R) in four hospitals in three Romanian cities: Cluj-Napoca, Satu Mare, and Sighetu-Marmatiei. The study population included third-trimester women attending antenatal clinics $(n=418) ; 364$ subjects were included in the analytic sample. We used the Center for Epidemiologic Studies Depression Scale (CES-D) as a "gold standard". We assessed reliability, validity, and conducted sensitivity analysis to establish an EPDS-R cutpoint. We found that reliability was robust $(\alpha=0.89)$ and there was a significant linear relationship between EPDS-R and CES-D scores $(r=0.77 ; p<0.001)$. We established an EPDS-R cutpoint of $>12$ to balance sensitivity and specificity. Principal component analysis revealed a two-factor solution. We detected antenatal depressive symptoms prevalence rates of $32 \%$ (CES-D) and 38\% (EPDS-R). This is the first study to report exclusively on antenatal depression and the use of the EPDS in Central and Eastern Europe. The EPDS-R is easy to administer, reliable, and valid for screening depression among antenatal women in Romania.

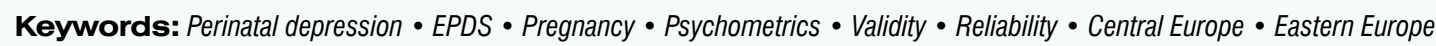
(C) Versita Sp. z 0.0 . 


\section{Introduction}

Perinatal ${ }^{1}$ depression is a well-recognized, serious complication of pregnancy. Combined point prevalence estimates based on international studies indicate that between $6.5 \%$ and $12.9 \%$ of women experience depression at some point during or after pregnancy [1]. Perinatal depression is diagnosed by the same criteria as other depression, but is distinguished from general depression by its timing (antenatal through the $12^{\text {th }}$ month postpartum) and an anxiety component [2-4].

Depression associated with pregnancy may be a manifestation of chronic depression unrelated to pregnancy or it may begin during pregnancy or following delivery. Most recent research to date has focused on postnatal depression, which is associated with lower quality mother-child interaction, missed pediatric appointments, greater use of emergency department services, higher levels of psychiatric disturbance among children, and greater child insecurity in attachment relationships [5-9]. Field's review of antenatal depression effects on early child development noted associations with excessive activity and growth delays in the fetus, prematurity, low birthweight, and less responsiveness [10].

The prevalence of perinatal depression in Central and Eastern Europe is unknown. In Romania, as in other countries in the region, pregnant and postpartum women are not screened for depression or other mental health conditions. There is a need to understand the prevalence of perinatal depression and to locate a relatively quick, easily administered screening instrument that can be used in antenatal care and in postnatal family care settings. Once identified, depression is a treatable condition and there is evidence that treatment benefits both mother and child [11-13].

The purpose of this study was to pilot and validate a depression screening tool for routine use, particularly in antenatal clinics that would be linguistically and culturally appropriate, psychometrically valid and reliable, and easy to administer and score.

\section{Materials and methods}

We conducted a cross-sectional, survey-based study to assess the reliability and validity of a linguistically and culturally appropriate Romanian version of the EPDS (EPDS-R). We further determined the optimum cutpoint of the EPDS-R scale for identifying depressive symptoms in this population of pregnant Romanian women.

1 Perinatal refers to the period between the $20^{\text {th }}$ week of gestation and the end of the $28^{\text {th }}$ day postpartum.
The study was a collaboration between public health researchers in the USA and Romania. US research team members were on site at various points during the study and the team met regularly via Elluminate internet meeting software [14] to review instrument development, study design, data collection, data management, and analysis.

\subsection{Setting}

This study was conducted in four hospitals with antenatal clinics in three cities in Romania: Cluj-Napoca, Satu Mare, and Sighetu-Marmatiei (Sighet). Cluj-Napoca is the second largest city in Romania with a population of just over 300,000. Satu Mare has a population of just over 100,000 and is located in northwest Romania. Sighet is a small city of about 40,000 located in northern Romania on the Ukrainian border [15]. In Cluj-Napoca, we recruited women and administered the interview in two academic maternity hospitals; in Satu Mare and Sighet, we recruited women attending antenatal clinics in two general hospitals. The study was conducted as collaboration between public health and medical researchers and students at Babeş-Bolyai University, Cluj-Napoca, and the University of lowa.

\subsection{Participants}

Participants were pregnant women, >18, attending antenatal clinic in hospital settings. Exclusion criteria included age $<18$ or any medical or cognitive condition or limitation that would prevent completion of the questionnaire. All eligible women in antenatal units were approached and recruited during clinic hours between July and September 2007. A total of 418 subjects signed Romanian language consent forms (173 in Cluj, 95 in Satu Mare, and 147 in Sighet). All data collection materials and procedures were approved by the public health Institutional Review Board (IRB) of the Babeş-Bolyai University Cluj-Napoca; analysis was exempted by the University of lowa Biomedical IRB (IRB-01) because of thorough de-identification of all subject records prior to analysis. Both university IRBs conform to the ethical standards described in the 1964 Declaration of Helsinki. All women received a small thank-you gift.

\subsection{Measures}

Participants completed self-administered questionnaires that included demographic information and two depression screening scales. 


\subsubsection{Edinburgh Postnatal Depression Scale (EPDS)}

The EPDS is a 10-item self-report depression screen validated for use during both the antenatal and postnatal periods $[2,16]$. It has been used in numerous populations and countries; however, to our knowledge, it has not been used in Central/Eastern Europe. The EPDS takes less than five minutes to complete. Responses to each question are scored and summed; possible scores range from 0 to 30 . The Scotlandbased authors of the EPDS note that a score of $>10$ suggests "possible depression" and that women with scores $>13$ should be referred to a clinician. A positive response to item 10 (suicidal thoughts) should always be noted and followed up $[2,16]$.

We developed a Romanian language version of the EPDS, which we called the EPDS-Romanian version (EPDS-R). EPDS-R items are shown in parallel with the original EPDS items in Table 1.

Bilingual research staff completed the initial translation and conducted a back-translation. The translation was reviewed by research team members in addition to Romanian sociology and linguistics faculty. Minor

Table 1. Original English and Romanian versions of EPDS items.

\begin{tabular}{|c|c|}
\hline Original version (EPDS) & Romanian version (EPDS-R) \\
\hline In the past 7 days: & În ultimele 7 zile: \\
\hline 1. I have been able to laugh and see the funny side of things & 1. Ați putut să râdeți şi să vedeți partea amuzantă a lucrurilor? \\
\hline As much as I always could & Atât de mult cât ați putut întotdeauna \\
\hline Not quite so much now & Nu prea în această perioadă \\
\hline Definitely not so much now & Aproape deloc în această perioadă \\
\hline Not at all & Deloc \\
\hline 2. I have looked forward with enjoyment to things & 2. Ați aşteptat cu bucurie ca unele lucruri să se întâmple? \\
\hline As much as I ever did & Atât cât ați fâcut-o întotdeauna \\
\hline Rather less than I used to & Mai degrabă mai puțin decât înainte \\
\hline Definitely less than I used to & Cu siguranțâ mai puțin decât înainte \\
\hline Hardly at all & Chiar deloc \\
\hline *3. I have blamed myself unnecessarily when things went wrong & *3. V-ați învinovățit fără rost atunci când lucrurile au mers prost? \\
\hline Yes, most of the time & Da, majoritatea timpului \\
\hline Yes, some of the time & Da, o parte din timp \\
\hline Not very often & Nu foarte des \\
\hline No, never & $\mathrm{Nu}$, niciodată \\
\hline 4. I have been anxious or worried for no good reason & 4. Ați fost agitată sau îngrijorată fără vreun motiv întemeiat? \\
\hline No, not at all & $\mathrm{Nu}$, deloc \\
\hline Hardly ever & Aproape niciodată \\
\hline Yes, sometimes & Da, câteodată \\
\hline Yes, very often & $\mathrm{Da}$, foarte des \\
\hline *5. I have felt scared or panicky for no very good reason & *5. V-ați simțit speriată sau panicată fără un motiv întemeiat? \\
\hline Yes, quite a lot & Da, destul de des \\
\hline Yes, sometimes & Da, câteodată \\
\hline No, not much & $\mathrm{Nu}$, nu foarte des \\
\hline No, not at all & $\mathrm{Nu}$, deloc \\
\hline${ }^{*} 6$. Things have been getting on top of me & *6. Ați simțit că vă depâşesc lucrurile în ultimul timp(vă copleșesc)? \\
\hline Yes, most of the time I haven't been able to cope at all & Da, majoritatea timpului nu ați putut face față deloc \\
\hline Yes, sometimes I haven't been coping as well as usual & Da, câteodată nu ați făcut față la fel de bine ca de obicei \\
\hline No, most of the time I have coped quite well & Nu, majoritatea timpului ați fắcut față chiar bine \\
\hline No, have been coping as well as ever & Nu, ați făcut față la fel de bine ca întotdeauna \\
\hline *7. I have been so unhappy that I have had difficulty sleeping & *7. V-ați simțit atât de nefericită încât să aveți probleme cu dormitul? \\
\hline Yes, most of the time & $\mathrm{Da}$, majoritatea timpului \\
\hline Yes, sometimes & Da, câteodată \\
\hline Not very often & Nu foarte des \\
\hline No, not at all & $\mathrm{Nu}$, deloc \\
\hline *8. I have felt sad or miserable & *8. V-ați simțit tristă sau nefericită? \\
\hline Yes, most of the time & Da, majoritatea timpului \\
\hline Yes, quite often & $\mathrm{Da}$, destul de des \\
\hline Not very often & Nu foarte des \\
\hline No, not at all & $\mathrm{Nu}$, deloc \\
\hline * 9 I have been so unhappy that I have been crying & *9. V-ați simțit atât de nefericită încât să plângeți? \\
\hline Yes, most of the time & $\mathrm{Da}$, destul de des \\
\hline Yes, quite often & Câteodată \\
\hline Only occasionally & Aproape niciodată \\
\hline No, never & Niciodată \\
\hline * 10 . The thought of harming myself has occurred to me & *10. V-ați gândit la a vă face rău singurâ? \\
\hline Yes, quite often & Da, destul de des \\
\hline Sometimes & Câteodată \\
\hline Hardly ever & Aproape niciodată \\
\hline Never & Niciodată \\
\hline
\end{tabular}

Items 1, 2, \& 4 are scored 0, 1, 2, or 3, with top response scored as 0 and bottom response scored as 3 .

Items 3, 5-10 are reverse-scored, with the bottom response scored as 0. 
modifications were implemented based on this review. The most important difference between the English-language EPDS and the EPDS-R, apart from language, is that the EPDS-R items are phrased as questions in the second person plural rather than as statements in the first person singular. Input from the sociologist, linguist, and Romanian members of the research team strongly recommended use of the second person plural, which is the Romanian polite form of address and considered more appropriate to research participants.

The questionnaire was piloted with a small sample $(n=20)$ of women seeking antenatal care in Cluj; these subjects were not included in the final study sample. Following pilot testing and training of data collectors, minor language changes were made to further ensure semantic, cultural, and technical accuracy.

\subsubsection{Center for Epidemiologic Studies Depression (CES-D)}

The CES-D is a 20-item instrument developed by the Center for Epidemiologic Studies, US National Institutes of Mental Health (NIMH) [17-19]. The CES-D was developed to identify depression in the general population; items measure both affective and somatic aspects of depression. The CES-D has been used globally in both clinical and population studies [20]. Possible scores range from 0 to 60 , with higher scores indicating the presence of more depressive symptomology; the cutpoint recommended by NIMH for clinical referral is >16 [17].

The CES-D has been used previously in Romania to screen for depression [21] although the translated instrument is not published. Therefore, we translated the instrument into Romanian and then back-translated and revised following the same procedures described above for the EPDS-R. We used our revised CES-D (R) in this study to examine concurrent validity and as a "gold standard" for establishing sensitivity and specificity of the EPDS-R and evaluation of cutpoints.

\subsection{Data Collection}

A team of public health and psychology students from Babeş-Bolyai University was trained to enroll women and administer the questionnaires. Students recruited women and collected data in the antenatal clinic and maternity units Monday through Thursday of each week. Students entered data into a WebSurveyor [22] form to facilitate data management and analysis by team members in both the US and Romania, following procedures developed by the research team in a prior study [23].

\section{Statistical methods}

Analysis of de-identified data was conducted at the University of lowa. Data were exported from WebSurveyor into IBM SPSS Statistics 19 [24] for analysis and verified for accuracy, completeness, and duplicate entries. All statistical analyses were conducted using SPSS with the exception of the ROC analysis, which we conducted using STATA I/C version 10 [25], since it produces a more complete range of ROC statistics than SPSS. Duplicates and records with data missing in $>20 \%$ within a single scale were removed $(n=54)$. Where $<20 \%$ of responses were missing in any one scale, missing values were imputed and replaced with series mean score for that item [26].

Univariate statistics were computed to describe respondents' demographic characteristics and scale scores. Total sample size was deemed appropriate to estimate reliability coefficients (internal consistency) using Cronbach's alpha ( $\alpha$ ) [27-29]. We examined the linear relationship between EPDS-R and CES-D(R) scores to assess concurrent validity using the Pearson product-moment correlation coefficient $(r)$. Preliminary analysis was conducted to ensure no violation of the assumptions of normality, linearity, or heteroskedasticity.

Descriptive and reliability analyses were conducted using the largest valid sample possible for each measure; that is, instead of truncating the entire data set to 364 due to missing or invalid CES-D responses, we used an $n$ of 395 for the EPDS-R (total number of valid responses) and an $n$ of 364 for CES-D(R) analyses. In this way, we were able to capture the greatest possible analytic power for each scale. For analyses involving both scales (e.g., principal components analysis), we used the smaller number $(n=364)$ for a matched sample.

Sensitivity and specificity of the EPDS-R was calculated using depressed/non-depressed cases identified by an established CES-D cutpoint as the "gold standard" for case detection [17,30]. Receiver Operating Characteristic (ROC) curve analysis measured the ability of the continuous EPDS-R score to correctly classify women with and without clinically important depressive symptoms. We constructed ROC curves by plotting sensitivity on the y-axis and 1-specificity on the $x$-axis for all EPDS-R scores. The summary statistic for the ROC curve is the area under the curve (AUC). The closer the curve is to the upper left corner of the graph indicates a bigger AUC and thus, a more accurate test [31]. (An AUC=1 indicates perfect agreement and 0.5 indicates that there is no more than random agreement.) For each score, we computed sensitivity and specificity for each possible cutpoint, weighing 
the trade-off between increased sensitivity (false-positives) and decreased specificity (true-negatives).

Construct validity was established using principal component analysis (PCA) with varimax rotation to confirm the internal structure of the EPDS-R.

\section{Results}

\subsection{Sample Characteristics}

From a total of 418 participants, we removed 54 incomplete records (e.g., questionnaires with both scales missing $>20 \%$ of responses) and analyzed data from 364 valid records. The mean age in the analytical sample was 27 (range 17-40 years) (Table 2). Just under half of women $(45 \%$; 163) had completed secondary education and $21 \%$ (76) completed university-level education. Most (71\%) were married and 45\% (162) were employed. Participants differed by city on all characteristics except gravidity (slightly over half of women in all three groups were primigravid). Subjects recruited in Cluj were better educated, more likely to consider themselves "urban," and more likely to describe themselves as ethnically Romanian than subjects from the other two study locations.

\subsection{Reliability and Validity}

The mean EPDS-R score was 10.1 (SD:6.5), with scores ranging from 0 to 29 . The mean $\operatorname{CESD}(\mathrm{R})$ score was 24.7 (SD:13.1), with scores ranging from 7 to 60 .

As indicated by Cronbach's alpha, reliability (internal consistency) for both EPDS-R and CES-D(R) scores were robust ( $\alpha=0.88$ and 0.93 , respectively) in this study sample. The slope of the regression line $(r=0.77$;

Table 2. Characteristics of study subjects by city. $p<.001)$ for the EPDS-R and the CES-D(R) indicated a strong, positive association between the two sets of scores. For the EPDS-R, we found solid item-total correlations (0.51-0.74) and a mean inter-item correlation of 0.43 . We report a wider range of item-total correlations for the CES-D(R) (0.51-0.80) and a mean inter-item correlation of 0.35 . The reason for the lower item-total and mean inter-item correlation for the CES-D(R), is likely due to the larger number of scale items and variability in how the CES-D measures depression (i.e., it uses more items and more types of items than the EPDS) [32].

\subsection{ROC Curve Analysis}

We examined EPDS-R sensitivity, specificity, and cutpoints based on the published CES-D score $>16$ as the reference value [17]. Figure 1 is the ROC curve, which depicts the performance of the EPSD-R in detecting depressive symptomology at each possible cutpoint. The strong AUC with a narrow confidence interval (0.88;

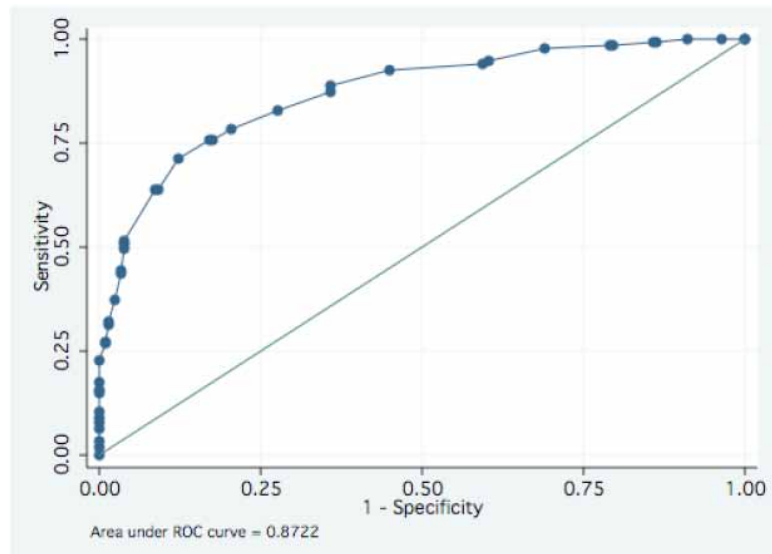

Figure 1. ROC Curve for EPDS-R

\begin{tabular}{|c|c|c|c|c|c|}
\hline Characteristic & All $(n=417)$ & Cluj $(n=173)$ & Satu Mare $(n=95)$ & Sighet $(n=147)$ & Significance (p-value) \\
\hline $\begin{array}{l}\text { Age (years) } \\
\text { Range } \\
\text { Mean }\end{array}$ & $\begin{array}{c}n=382 \\
18-43 \\
27.0 \text { (SD: } 5.4)\end{array}$ & $\begin{array}{c}18-40 \\
27.8 \text { (SD: 5.2) }\end{array}$ & $\begin{array}{c}18-37 \\
27.1 \text { (SD: 4.7) }\end{array}$ & $\begin{array}{c}18-43 \\
25.7 \text { (SD: 5.9) }\end{array}$ & $p=.005$ \\
\hline $\begin{array}{l}\text { Education } \\
\text { Secondary } \\
\text { University }\end{array}$ & $\begin{array}{c}\mathrm{n}=371 \\
256(61.4) \\
61(14.6)\end{array}$ & $\begin{array}{l}86(49.7) \\
48(27.8)\end{array}$ & $\begin{array}{l}62(65.3) \\
11(11.6)\end{array}$ & $\begin{array}{c}107(72.8) \\
2(1.4)\end{array}$ & $\begin{array}{l}p<.0001 \\
p<.0001\end{array}$ \\
\hline $\begin{array}{l}\text { Marital status } \\
\text { Married }\end{array}$ & $\mathrm{n}=295(70.7)$ & $143(82.7)$ & $76(80.0)$ & $74(50.3)$ & $\mathrm{p}<.0001$ \\
\hline $\begin{array}{l}\text { Gravidity } \\
\text { Primigravid }\end{array}$ & $n=235(56.4)$ & $96(55.5)$ & $54(56.3)$ & $88(57.5)$ & ns \\
\hline $\begin{array}{l}\text { Employed } \\
\text { Yes }\end{array}$ & $\mathrm{n}=186(44.6)$ & $56(32.4)$ & $30(31.3)$ & $106(69.3)$ & $\mathrm{p}<.0001$ \\
\hline $\begin{array}{l}\text { Residence } \\
\text { Urban } \\
\text { Rural }\end{array}$ & $\begin{array}{c}\mathrm{n}=403 \\
231(56.4) \\
172(41.3)\end{array}$ & $\begin{array}{c}124(71.7) \\
46(26.6)\end{array}$ & $\begin{array}{l}53(55.8) \\
38(40.0)\end{array}$ & $\begin{array}{l}52(35.4)) \\
88(59.9)\end{array}$ & $\mathrm{p}<.0001$ \\
\hline $\begin{array}{l}\text { Ethnicity } \\
\text { Romanian } \\
\text { Hungarian } \\
\text { Roma }\end{array}$ & $\begin{array}{c}\mathrm{n}=409 \\
305(73.1) \\
72(17.3) \\
20(4.8)\end{array}$ & $\begin{array}{c}142(82.1) \\
22(12.7) \\
8(4.6)\end{array}$ & $\begin{array}{c}63(66.3) \\
24(25.3) \\
1(1.1)\end{array}$ & $\begin{array}{c}98(66.7) \\
26(17.7) \\
11(7.5)\end{array}$ & $p<.0001$ \\
\hline
\end{tabular}


95\% Cl: 0.85-0.91) indicated high concordance with the CES-D. We selected $>12$ as the optimal cutpoint for antenatal screening with correct classification of $81.1 \%$ of cases (Se: 75.8; Sp: 84.8). Table 3 shows potential cutpoints with corresponding sensitivity, specificity, and correct classification values.

Table 3. Sensitivity and specificity of the EPDS-R.

\begin{tabular}{|c|c|c|c|}
\hline Cutpoint (score) & Sensitivity & Specificity & Correctly classified $^{a}$ \\
\hline $1-9$ & $100-87.6 \%$ & $0-64.1 \%$ & $42.3-74.0 \%$ \\
\hline 10 & $83.0 \%$ & $72.3 \%$ & $76.8 \%$ \\
\hline 11 & $78.4 \%$ & $79.4 \%$ & $79.0 \%$ \\
\hline 12 & $75.8 \%$ & $82.8 \%$ & $79.8 \%$ \\
\hline 13 & $71.2 \%$ & $87.6 \%$ & $80.7 \%$ \\
\hline 14 & $64.1 \%$ & $91.4 \%$ & $79.8 \%$ \\
\hline 15 & $49.7 \%$ & $91.4 \%$ & $79.8 \%$ \\
\hline $16-28$ & $43.8-0 \%$ & $96.7-100.0 \%$ & $13.1 \%-$ not calculable \\
\hline
\end{tabular}

${ }^{a}$ Correctly classified refers to a STATA procedure that uses a cutpoint of $50 \%$ to predict the probability of identifying true cases.

Selection of an appropriate cutpoint requires a balance of sensitivity and specificity. Weighing the two - comparing the possibility of more false positives against more true positives - is important and may depend on local resources and culture. In many situations, it may be more important to identify and refer as many women who display depressive symptomology as possible, and then refer them to mental health professionals for a complete evaluation. This approach would enable identification and treatment of as many true positives as possible. However, Romania has only a small reserve of mental health professionals and medical schools do not provide thorough training in mental health. Given this situation, we think it is more important to choose a cutpoint that maximizes specificity (without losing too much sensitivity) in order to save resources and ensure that there are enough professionals available to fully evaluate women who screen positive based on the EPDS.

\subsection{Principal Component Analysis (PCA)}

We examined Kaiser-Meyer-Olkin (KMO) and Bartlett's test of sphericity to determine if the EPDS$\mathrm{R}$ data were appropriate for PCA. Adequate KMO should be above 0.5 ; we observed 0.90 for the EPDS$\mathrm{R}$, indicating appropriate distribution. Bartlett's test of sphericity, which tests whether the correlation matrix is an identity matrix and thus inappropriate for PCA was found to be significant at the $p<.0001$ level and therefore appropriate [31]. PCA, with varimax rotation, indicated two factors with eigenvalues $>1$, together accounting for $63.2 \%$ of the observed variance. Examination of items with component loadings of at least 0.40 were considered in subscale determination. The two factors loaded heavily on items reflecting (1) dys-
Table 4. Factor loadings for EPDS-R items based on PCS with varimax rotation.

\begin{tabular}{|l|c|c|}
\hline Items & $\begin{array}{c}\text { Factor 1 } \\
\text { (sadness/ } \\
\text { anxiety) }\end{array}$ & $\begin{array}{c}\text { Factor 2 } \\
\text { (unhappiness/ } \\
\text { suicidality) }\end{array}$ \\
\hline $\begin{array}{l}\text { 5. I have felt scared or panicky for } \\
\text { no very good reason. }\end{array}$ & .770 & \\
\hline $\begin{array}{l}\text { 3. I have blamed myself unneces- } \\
\text { sarily when things went wrong. }\end{array}$ & .746 & \\
\hline $\begin{array}{l}\text { 9. I have been so unhappy that I } \\
\text { have been crying. }\end{array}$ & .708 & \\
\hline $\begin{array}{l}\text { 6. Things have been getting on top } \\
\text { of me. }\end{array}$ & .703 & \\
\hline 8. I have felt sad or miserable. & .651 & \\
\hline $\begin{array}{l}\text { 4. I have been anxious or worried } \\
\text { for no good reason. }\end{array}$ & .590 & .458 \\
\hline $\begin{array}{l}\text { 7. I have been so unhappy that I } \\
\text { have had difficulty sleeping. }\end{array}$ & .578 & .871 \\
\hline $\begin{array}{l}\text { 2. I have looked forward with enjoy- } \\
\text { ment to things. }\end{array}$ & .497 & .569 \\
\hline $\begin{array}{l}\text { 1. I have been able to laugh and } \\
\text { see the funny side of things. }\end{array}$ & & \\
\hline $\begin{array}{l}\text { 10. The thought of harming myself } \\
\text { has occurred to me. }\end{array}$ & & \\
\hline
\end{tabular}

phoria and anxiety (7 items) and (2) anhedonia/suicidality (3 items) (see Table 4). A two-factor solution is consistent with the literature from other populations [33-35]. We examined the two subscales for internal consistency and found strong correlation coefficients for each factor $\left(\alpha_{1}=0.87 ; \alpha_{2}=0.78\right)$.

\subsection{Depression Prevalence}

The mean EPDS-R score was 10.5 (SD: 6.4); the mean CES-D(R) score was 24.7 (SD:13.1). Based on the published cutpoint score of $>16$ for the CES-D, we detected a depression prevalence rate of $31.9 \%$ $(n=117)$; with the cutpoint recommended by the original EPDS authors of $>10$, we report a prevalence rate of $41.0 \%$. Using our recommended EPDS-R cutpoint of $>12$, the prevalence rate of depressive symptoms was $33.7 \%$. Seventy-two (18.2\%) women reported that they had "sometimes" or "quite often" contemplated suicide.

\section{Discussion}

This study of Romanian pregnant women is the first one we are aware of to evaluate the performance of the EPDS in Romania. In our study, the EPDS-R exhibited robust psychometric properties for the population overall and for the three different cities. We recommend it as a valid, reliable, and easy-to-administer depression screening instrument for pregnant women in Romania. 


\subsection{Limitations and Strengths}

The biggest limitation of this study was the inability to use psychiatric examination based on DSM-IV criteria as the gold standard. Because there are too few trained psychiatric professionals in Romania, including at the study hospitals, it was not possible to conduct clinical evaluations. We chose the CES-D because of its wide use in general populations worldwide and its consistency in detecting depressive symptomology. The fact that the CES-D had been used previously in Romania made it the strongest and most viable candidate for comparison. Although we did not have access to the CES-D translation used in past research in Romania, we believe that our rigorous approach to linguistic and cultural translation made it an appropriate standard with which to compare the EPDS-R.

A corresponding strength is that this study also cross-validated the CES-D because we showed robust internal consistency and confirmed factor structure comparable to other studies. The higher rate of depressive symptomology detected by the EPDS-R suggests its higher sensitivity to the population of pregnant women studied. Therefore, a secondary benefit of this study is that we are able to provide a validated CES-D(R) for use in a general adult clinical population as well as the EPDS-R for perinatal patients.

Finally, we were unable to assess depression prior to pregnancy, so we cannot report on non-gestational depression as a baseline.

Other strengths of this study include its conduct in hospital settings with a relatively large sample of pregnant women, all in their third trimester. We enrolled women from three different cities in Romania, increasing our generalizability beyond a single setting.

\section{References}

[1] Gavin, N.I., et al., Perinatal depression: A systematic review of prevalence and incidence. Obstet Gynecol, 2005. 106(5 Pt 1): p. 1071-1083

[2] Cox, J., et al., Validation of the Edinburgh Postnatal Depression Scale (EPDS) in non-postnatal women. J Affect Disord, 1996. 39(3): p. 185-9

[3] Ritter, C., et al., Stress, psychosocial resources, and depressive symptomotology during pregnancy in low-income, inner-city women. Health Psychol, 2000. 19(6): p. 576-85

[4] Ross, L., et al., Measurement issues in postpartum depression, part 1: Anxiety as a feature of postpartum depression. Arch Womens Ment Health, 2003. 6(1): p. 51-7

\subsection{Future research}

Future research should continue to explore related psychosocial domains that represent risk to pregnant women, including stress, pregnancy-related distress, and their association with infant and maternal outcomes.

\subsection{Public health implications}

Antenatal screening of depression is critical to protect the health and development of the mother and infant. It is critical for mental health and public health professionals to note the high depressive symptoms rate observed in this population and to consider development of a professional cadre of trained mental health workers in psychology and psychiatry available to test and treat pregnant women. The EPDS-R is a quick, reliable, and valid measure that could be used by the attending physician or nurse to review the need for followup and treatment.

\section{Acknowledgments}

This study was funded in part by the US National Institutes of Health (NIH) Fogarty International Collaborative Training Program in Central Europe (5D43TW007261) and the NIH National Center on Minority Health and Health Disparities funded Minority Health and Health Disparities International Research and Training Program (T37 MD001453).

The authors wish to thank Cătălin Baba, Ph.D., Dean, Faculty Political, Communication Sciences Babeş-Bolyai University, Cluj-Napoca; Gabriela Zaharie, MD; Marta Mureşan, MD; Tunda Kovacs, MD; Diana Rus, Ioana Marincas, Natalia Blag, and Diana Miclaus. Without their enthusiastic support, the study would not have been possible.

[5] Boath, E., A. Pryce, and J. Cox, Postnatal depression: The impact on the family. J Reprod Infant Psychol, 1998. 16: p. 199-203

[6] Lovestone, S. and R. Kumar, Postnatal psychiatric illness: The impact on partners. $\mathrm{Br} \mathrm{J}$ Psychiatry, 1993. 163: p. 210-6

[7] Murray, L. and P. Cooper, Postpartum depression and child development. Psychol Med, 1997. 27: p. 253-60

[8] Murray, D., et al., The socio-emotional development of 5-year-old children of postnatally depressed mothers. J Child Psychol Psychiatry, 1999. 40: p. 1259-71 
[9] Caplan, H., et al., Maternal depression and the emotional development of the child. Br J Psychiatry, 1989. 154: p. 818-22

[10] Field, T., Prenatal depression effects on early development: A review. Infant Behav Dev, 2011. 34(1): p. 1-14

[11] Alwan, S., et al., National Birth Defects Prevention Study: Use of selective serotonin reuptake inhibitors in pregnancy and the risk of birth defects. N Engl J Med, 2007. 356: p. 2684-92

[12] Kulin, N., et al., Pregnancy outcome following maternal use of the new selective serotonin reuptake inhibitors: a prospective controlled multicenter study. JAMA, 1998. 279: p. 609-10

[13] Nulman, I., et al., Neurodevelopment of children exposed in utero to antidepressent drugs. $\mathrm{N}$ Engl J Med, 1997. 336

[14] Elluminate Live USA, Elluminate Live Academic Edition 7.0. 2006, Elluminate Live USA: Ft. Lauderdale, FL

[15] National Institute of Statistics, Populatie. Anuarul Statistic al Romaniei. 2007, National Institute of Statistics: Bucharest, Romania

[16] Cox, J.L., J.M. Holden, and R. Sagovsky, Edinburgh Postnatal Depression Inventory. 1987

[17] Radloff, L.S., The CES-D scale: A self report depression scale for research in the general population. Appl Psychol Meas, 1977. 1: p. 385-401

[18] Radloff, L.S., The use of the Center for Epidemiologic Studies Depression Scale in adolescents and young adults. Journal of Youth and Adolescence, 1991. 20: p. 149-165

[19] Radloff, L.S. and L. Teri, Use of the Center for Epidemiologic Studies Depression Scale with older adults. Clin Gerontol, 1986. 5: p. 119-135

[20] Shafer, A., Meta-analysis of the factor structures of four depression questionnaires: Beck, CES-D, Hamilton, and Zung. J Clin Psychol, 2006. 62(1): p. $123-46$

[21] Robila, M., Effects of economic pressure on marital conflict in Romania. J Fam Psychol, 2005. 19(2): p. $246-51$

[22] WebSurveyor Corporation, WebSurveyor. 2006, WebSurveyor Corporation: Herndon, VA
[23] Wallis, A.B., et al., An international model for staffing maternal and child health research: the use of undergraduate students. Breastfeed Med, 2007. 2(3): p. 139-44

[24] IBM, IBM SPSS Statistics 19. 2010: Chicago, IL

[25] StataCorp LE, Stata 10. 2007, StataCorp LP: College Station, TX

[26] Streiner, D.L. and G.R. Norman, Health Measurement Scales: A Practical Guide to their Development and Use. Second ed. 1998, Oxford: Oxford University Press

[27] Charter, R.A., Sample size requirements for precise estimates of reliability, generalizability, and validity coefficients. J Clin Exp Neuropsychol, 1999. 21(4): p. $559-66$

[28] Cronbach, L.J., Coefficient alpha and the internal structure of tests. Psychometrika, 1951. 16(3): p. 297-334

[29] Cronbach, L.J., My current thoughts on coefficient alpha and successor procedures. Educ Psychol Meas, 2004. 64(3): p. 391-418

[30] Radloff, L.S. and B.Z. Locke, The Community Mental Health Assessment Survey and the CES-D Scale, in Community Surveys, M. Weissman, J. Myers, and C. Ross, Editors. 1986, Rutgers University Press: New Brunswick, NJ

[31] Juul, S., An Introduction to Stata for Health Researchers. 2006, College Station, TX: Stata Press

[32] Streiner, D.L. and G.R. Norman, Health Measurement Scales: A Practical Guide to Their Development and Use. 4th edition ed. 2008, Oxford: Oxford University Press

[33] Brouwers, E., A. van Baar, and V. Pop, Does the Edinburgh Postnatal Depression Scale measure anxiety? J Psychosom Res, 2001. 51(659-63)

[34] Ross, L., et al., Measurement issues in postpartum depression, Part 1: Anxiety as a feature of postpartum depression. Archives of Women's Mental Health, 2003. 6: p. 51-7

[35] Logsdon, M., W. Usui, and M. Nering, Validation of the Edinburgh postnatal depression scale for adolescent mothers. Arch Womens Ment Health, 2009. 12: p. $433-40$ 